\title{
The Effect of Different Levels of Matricaria chamomilla on Functional Status of the Liver in Rats Injected with Carbon Tetrachloride
}

\author{
Magbolah Salem Helal Alzahrani \\ Department of Biology, Faculty of Science, Al-Baha University, Al-Baha, Kingdom \\ of Saudi Arabia
}

\begin{abstract}
A B S T R A C T
Chamomile is a member of the Asteraceae family and has been well established as a medicinal plant. There are many different species of chamomile, the two most common being German chamomile (Marticaria chamomilla) and Roman chamomile (Chamaemelum nobile). The use of chamomile has been associated with calming and anti-inflammatory properties. The plant's healing properties come from its flowers, which contain volatile oils including bisabolol, bisabolol oxides A and B, and matricin as well as flavonoids. This study aims to elucidate the possible therapeutic applications of different levels of $M$. chamomilla on the functional status of liver, in rats injected with carbon tetrachloride $\left(\mathrm{CCl}_{4}\right)$, a known hepatotoxin. Thirty-six male albino rats were treated with subcutaneous injection of $\mathrm{CCl}_{4}$ in paraffin oil $50 \% \mathrm{~V} / \mathrm{V}(2 \mathrm{ml} / \mathrm{kg}$ b. wt.) twice a week for 2 weeks to induce chronic liver damage. After injection of $\mathrm{CCl}_{4}$, blood samples were obtained using the retro-orbital method to confirm liver damage and estimate liver function. Rats given $\mathrm{CCl}_{4}$ prior to feeding $M$. chamomilla demonstrated decrease in serum lipoprotein HDL, LDL, VLDL fraction levels, indicating liver damage. Rats given $\mathrm{CCl}_{4}$ and fed on $5 \% M$. chamomilla showed the most significant increase in organ weight as compared to all levels of treatment suggesting that $M$. chamomilla can reduce liver damage. Rats given $\mathrm{CCl}_{4}$ then fed on a combination of all levels of M. chamomilla showed a decrease of AST, ALT and ALP enzyme levels in the serum, suggesting a reduction in liver damage. This study showed that proceeding liver damage using $\mathrm{CCl}_{4}$ and administering $5 \% \mathrm{M}$. chamomilla, liver function improved significantly as shown with a reduction in serum AST, ALT and ALP, and use of M. chamomilla should be considered in combination therapy for treating liver disease or damage.
\end{abstract}

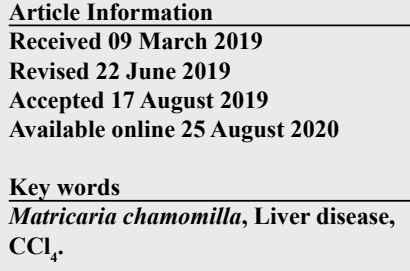

\section{INTRODUCTION}

$M$ atricaria chamomilla is a plant species from the Asteraceae family which has medicinal properties. It has been referred to as the star among medicinal species (Singh, 2011). Various functions of the plant has been established which include cosmetic, nutritional and medicinal properties. It has been used for a variety of different ailments including nervousness, anxiety, and headaches. Its anti-inflammatory properties as well as its relaxing and soothing functionalities make it an excellent candidate for use in a variety of medical conditions. Many studies in the literature have researched the use of chamomile to treat a variety of illness's including small bowel inflammation, intestinal mucositis and rheumatoid arthritis. However, its use in treating liver damage is not as well studied.

Most of the studies pertaining to drug induced toxicity employ liver as a target organ. This is because, liver is

\footnotetext{
Corresponding author: mshzahrani@bu.edu.sa 0030-9923/2020/0006-2111 \$ 9.00/0

Copyright 2020 Zoological Society of Pakistan
}

responsible for the antioxidative properties of the body as well as metabolism, secretion and storage of substances making it one of the most vital organs of the body (Madrigal-Santillán et al., 2014). Drug and alcohol abuse can cause liver damage and may require transplantation in extreme cases. The use of plant based products has been studied to treat liver disease but little is known about how the use of such products occurs (Guan and $\mathrm{He}, 2015$ ). $\mathrm{CCl}_{4}$ is well known hepatotoxin and its role of in induction of liver damage and subsequent oxidative stress has been reported elsewhere (Bhattacharjee and Sil, 2007; Aksoy and Sozbilir, 2012).

This investigation aims to study the possible therapy of different levels of $M$. chamomilla on functional status of liver in rats injected with carbon tetrachloride $\left(\mathrm{CCl}_{4}\right)$, a well-known liver toxin which has been used widely in research to induce liver damage. Some studies have shown that the use of $M$. chamomilla can reduce enzymes linked to liver damage (Srivastava et al., 2010). This study examines the serum enzyme levels of $\mathrm{CCl}_{4}$ treated rats, and also to identify the ideal concentration of $M$. chamomilla in treating liver damage. Using this data a more personalized approach in treating liver damage with 
M. chamomilla may be applied. This study also examines food intake, bilirubin levels and organ size to ascertain what concentration is ideal in treating liver damage.

\section{MATERIALS AND METHODS}

\section{Plants}

M. chamomilla plants were purchased as dried material from the local market, while others were obtained as raw plants from local green groceries.

\section{Basal diet}

The basal diet was prepared following standard procedure (Reeves et al., 1993). It consisted of 20\% protein (casein), $10 \%$ sucrose, $4.7 \%$ corn oil, $2 \%$ choline chloride, $1 \%$ vitamin mixture, $3.5 \%$ salt mixture and $5 \%$ fiber (cellulose). The remainder was corn starch. The salt mixture comprised $(\mathrm{g} / 100 \mathrm{~g}) \mathrm{CaCO}_{3}, 600 \mathrm{mg} ; \mathrm{K}_{2} \mathrm{HPO}_{4}$, $645 \mathrm{mg}$; $\mathrm{Ca} \mathrm{HPO}_{4} 2 \mathrm{H}_{2} \mathrm{O}, 150 \mathrm{mg} ; \mathrm{MgSO}_{4} 2 \mathrm{H}_{2} \mathrm{O}, 204 \mathrm{mg}$; $\mathrm{NaCl}, 334 \mathrm{mg}$; $\mathrm{Fe}\left(\mathrm{C}_{6} \mathrm{H}_{5} \mathrm{O}_{7}\right)_{2} \cdot 6 \mathrm{H}_{2} \mathrm{O}, 55 \mathrm{mg} ; \mathrm{Kl}, 1.6 \mathrm{mg}$; $\mathrm{MnSO}_{4} \cdot 4 \mathrm{H}_{2} \mathrm{O}, 10 \mathrm{mg} ; \mathrm{ZnCl}_{2}, 0.5 \mathrm{mg}$ and $\mathrm{Cu} \mathrm{SO}_{4} .5 \mathrm{H}_{2} \mathrm{O}$, $0.06 \mathrm{mg}$ (Hegsted et al., 1941). The vitamin mixture comprised: vitamin E, $10 \mathrm{IU}$; vitamin $\mathrm{K}, 0.50 \mathrm{IU}$; vitamin A, $200 \mathrm{IU}$; thiamin, $0.50 \mathrm{mg}$; pyridoxine, $1.00 \mathrm{mg}$; niacin, $4.00 \mathrm{mg}$; Calcium panthothenic acid, $0.40 \mathrm{mg}$; vitamin D, $100 \mathrm{IU}$; choline chloride, $200 \mathrm{mg}$; folic acid, $0.02 \mathrm{mg}$; inositol, $24 \mathrm{mg}$; para-amino - benzoic acid, $0.02 \mathrm{mg}$; vitamin B12, $2.00 \mu \mathrm{g}$ and biotin, $0.02 \mathrm{mg}$ (Campbell,1963).

\section{Experimental diet}

The experimental diet consisted of the basal diet plus $10 \mathrm{~g}$ of different concentrations of $M$. chamomilla ranging from $5-25 \%$. Each group is outlined below along with concentration added to each basal diet (Table I).

\section{Carbon tetra chloride}

Carbon tetrachloride $\left(\mathrm{CCl}_{4}\right)$ was obtained from ElGomhoryia Company for Chemical Industries, Cairo,
Egypt as $10 \%$ liquid solution. It was dispensed in white plastic bottles each containing one liter as a toxic chemical material for liver poisoning according to Passmore and Eastwood, 1986. In the same time, it is mixed with paraffin oil which obtained from the pharmacy for dilution during the induction.

\section{Rats}

Mature male albino rats of Sprague-Dawley strain weighing 150-160 g body weight at age of 14-16 weeks were obtained from Laboratory of Animal Colony, Helwan, Egypt. The animals were allocated in plastic cages with metallic stainless covers and kept under strict hygienic measures. Rats were fed with basal diet for 7 days before the beginning of the experiment for adaptation. Diets were presented to rats in special non-scattering feeding cups to avoid loss of food and contamination. Water was provided ad libitum via a narrow mouth bottle with a metallic tube tightly fixed at its mouth by a piece of rubber tube. Animals were subjected to a $12 \mathrm{~h}$ light and $12 \mathrm{~h}$ dark schedule and kept for 7 days before the start of the experiment for acclimatization as noted before.

\section{Plant preparation}

The plant materials were grinded in a mixer to give a powder and were kept in dusky stoppered glass bottles in a cool and dry location to reduce oxidation of their contents.

\section{Grouping and feeding of rats}

All the rats were fed for one week on basal diet before starting the experiment, then divided into two main groups, the first group ( $\mathrm{n}=6$ rats) was fed on the basal diet only for 28 days. The rats of second main group ( $\mathrm{n}=36$ rats) were injected subcutaneously by $\mathrm{CCl}_{4}$ to induce liver damage according to Jayasekhar et al. (1997). Rats with liver intoxication were divided into following groups $(\mathrm{n}=6$ rats): Group 1 is a control positive and fed on basal diet for 28 days, Group 2A received basal diet plus $5 \%$ M. chamomilla, Group 2B got basal diet plus $10 \% \mathrm{M}$. chamomilla,

Table I.- The composition of basal and experimental diet.

\begin{tabular}{|c|c|c|c|c|c|c|}
\hline \multirow[t]{2}{*}{ Component (g) } & \multirow[t]{2}{*}{ Basal diet } & \multicolumn{5}{|c|}{ Concentration of $M$. chamomilla } \\
\hline & & $5 \%$ & $10 \%$ & $15 \%$ & $20 \%$ & $25 \%$ \\
\hline Test ingredients & - & 10 & 10 & 10 & 10 & 10 \\
\hline Casein & 20 & 20 & 20 & 20 & 20 & 20 \\
\hline Corn oil & 4.7 & 4.7 & 4.7 & 4.7 & 4.7 & 4.7 \\
\hline Mineral mix & 3.5 & 3.5 & 3.5 & 3.5 & 3.5 & 3.5 \\
\hline Vitamin mix & 1 & 1 & 1 & 1 & 1 & 1 \\
\hline Cellulose & 5 & 5 & 5 & 5 & 5 & 5 \\
\hline Cholin chloride & 2 & 2 & 2 & 2 & 2 & 2 \\
\hline Sucrose & 10 & 10 & 10 & 10 & 10 & 10 \\
\hline Corn starch & Up to 100 & Up to 100 & Up to 100 & Up to 100 & Up to 100 & Up to 100 \\
\hline
\end{tabular}


Group 2C fed with basal diet plus 15\% M. chamomilla, Group 2D received basal diet plus 20\% M. chamomilla and Group 2E fed with basal diet plus 25\% M. chamomilla.

\section{Induction of liver intoxication in rats}

Thirty-six male albino rats were treated with subcutaneous injection of $\mathrm{CCl}_{4}$ in paraffin oil $50 \% \mathrm{~V} / \mathrm{V}$ $(2 \mathrm{ml} / \mathrm{kg} \mathrm{B}$. Wt.) twice a week for 2 weeks to induce chronic damage of the liver according to the method described by Jayasekhar et al. (1997). After the injection of $\mathrm{CCl}_{4}$, blood samples were obtained by retro-orbital method to ensure occurrence of liver injury and to estimate liver function.

\section{Blood sampling}

At the end of the experiment period (28 days) rats were sacrificed by ether and anesthesia. Blood samples were obtained by retro-orbital method in a clean dry centrifuge tube. They were left to clot by standing at room temperature for $20 \mathrm{~min}$, and then centrifuged at 1500 r.p.m for $15 \mathrm{~min}$. Serum samples were collected by a dry clean syringe, poured in Wisserman tubes and then kept frozen in a refrigerator at $-10^{\circ} \mathrm{C}$ for biochemical analysis. Rats were thereafter opened, liver, spleen, heart, lungs and kidneys removed and washed in saline solution, then dried and weighed. Relative weights of mentioned organs were calculated using the following formula:

$$
\text { Relative organ weight }=\frac{\text { Organ weight }}{\text { Body weight }} \times 100
$$

For fixation prior to histopathological investigation, organs were kept in formalin solution $(10 \% \mathrm{~V} / \mathrm{V})$ according to methods described by Drury and Wallington (1967).

\section{Biological evaluation}

During the period of the experiment, all the rats were weighed once a week and the consumed diets were recorded everyday (daily food intake). At the end of the experiment, biological evaluation of the experimental diets was carried out by determination of body weight gain $(\%)(B W G \%)$ and food efficiency ratio (FER), according to method of Chapman et al., 1959, using the following formulae:

$$
\begin{gathered}
\text { BWG }(\%)=\frac{\text { Final weight }- \text { Initial weight }}{\text { Initial weight }} \times 100 \\
\text { FER }=\frac{\text { Body weight gain }(\mathrm{g})}{\text { Food intake }(\mathrm{g})}
\end{gathered}
$$

Food intake was also calculated daily.

\section{Determination of the activity of liver enzymes}

Determination of aspartate aminotransferase (AST) enzyme was carried out by spectrophotometer using specific kits (BioMerieux) according to Reitman and Frankel (1957). Alkaline phosphatase (ALP) and alanine aminotransferase (ALT) determination was based on colorimetric determination method of Roy (1970). Serum total bilirubin was determined colorimetrically as described by Doumas et al., (1973), using spectrophotometer adjusted at $578 \mathrm{~nm}$.

\section{Determination of components of lipid profile}

Total cholesterol was determined according to Ratliff and Hall (1973). Enzymatic colorimetric determination of triglycerides was carried out according to Jacobs and Van Denmark (1960). Determination of HDL was carried out according to the method of Fnedewaid (1972), and Gordon and Amer (1977). The determination of VLDL and LDL was carried out according to the method of Lee and Nieman (1996).

\section{Statistical analysis}

The obtained data were statistically analyzed using computerized SPSS (Statistic Program Sigmastat, statistical soft-ware, SAS Institute, Cary, NC). Effects of different treatments were analyzed by one way ANOVA (Analysis of variance) test using Duncan's multiple range test and $p<0.05$ was used to indicate significance between different groups (Snedecor and Cochran, 1967).

\section{RESULTS AND DISCUSSION}

Liver is the vital organ widely employed for toxicity studies. Chemical induced liver damage may be attributed to the toxicity of the parent compound or to the toxic metabolic products (Kuntz and Kuntz, 2005). In the present study $\mathrm{CCl}_{4}$ is utilized for inducing hepatoxicity in rats, owing to its similarity in mechanism of action in humans (Sancheti et al., 2013). Moreover, the hepatoprotectve activity of $M$. chamomilla against $\mathrm{CCl}_{4}$-induced liver injury in rats have not been reported. The present investigations try to elucidate the hepatoprotective activity of $M$. chamomilla against $\mathrm{CCl}_{4}^{-}$ induced liver injury in rats.

\section{Effect on food intake, body weight gain and feed efficiency ratio}

Data presented in Table II shows the effect of different levels of $M$. chamomilla on food intake (FI), body weight gain \% (BWG\%) and feed efficiency ratio (FER) in $\mathrm{CCl}_{4}$ - intoxicated rats. It could be observed for rats intoxicated with $\mathrm{CCl}_{4}(\mathrm{C}+\mathrm{ve})$ group that $\mathrm{FI}$ was significantly reduced $(15.05 \pm 0.038 \mathrm{~g} / \mathrm{day})$ compared to the $\mathrm{C}$-ve normal rats $(17.19 \pm 0.041 \mathrm{~g} /$ day $)$. All rats treated with $\mathrm{CCl}_{4}$ and fed on all tested concentration $(5 \%, 10 \%, 15 \%, 20 \%, 25 \%)$ of $M$. chamomilla had a significant increase in FI. Rats given $\mathrm{CCl}_{4}$ and fed on $10 \% \mathrm{M}$. chamomilla showed the most significant increase in FI compared to all levels of $M$. 
chamomilla, which reached to $19.09 \pm 0.015 \mathrm{~g} / \mathrm{day}$.

Table II.- Effects of the different levels of $M$. chamomilla $(5 \%, 10 \%, 15 \%, 20 \%, 25 \%)$ on FI (food intake), BWG\% (body weight gain) and FER (feed efficiency ratio) of $\mathrm{CCl}_{4}$-intoxicated rats ( $\mathrm{n}=6$ rats).

\begin{tabular}{lccc}
\hline $\begin{array}{l}\text { Parameters / } \\
\text { Groups }\end{array}$ & FI (g) & BWG (\%) & FER \\
\hline Control - ve & $17.19 \pm 0.04^{\mathrm{d}}$ & $35.78 \pm 0.97^{\mathrm{a}}$ & $0.13 \pm 0.007^{\mathrm{a}}$ \\
Control + ve & $15.05 \pm 0.03^{\mathrm{g}}$ & $10.24 \pm 0.62^{\mathrm{d}}$ & $0.06 \pm 0.003^{\mathrm{e}}$ \\
$5 \%$ M. chamomilla & $17.61 \pm 0.02^{\mathrm{c}}$ & $34.04 \pm 0.57^{\mathrm{a}}$ & $0.11 \pm 0.004^{\mathrm{b}}$ \\
$10 \%$ M. chamomilla & $19.09 \pm 0.01^{\mathrm{a}}$ & $33.58 \pm 0.45^{\mathrm{a}}$ & $0.11 \pm 0.006^{\mathrm{b}}$ \\
$15 \%$ M. chamomilla & $18.54 \pm 0.03^{\mathrm{b}}$ & $24.88 \pm 0.64^{\mathrm{b}}$ & $0.09 \pm 0.003^{\mathrm{c}}$ \\
$20 \%$ M. chamomilla & $16.46 \pm 0.02^{\mathrm{e}}$ & $14.37 \pm 0.41^{\mathrm{c}}$ & $0.08 \pm 0.004^{\mathrm{c}}$ \\
$25 \%$ M. chamomilla & $16.19 \pm 0.01^{\mathrm{f}}$ & $13.73 \pm 0.51^{\mathrm{c}}$ & $0.07 \pm 0.004^{\mathrm{d}}$ \\
\hline
\end{tabular}

Values denote arithmetic means \pm Standard error of the mean. Means with different letters $(\mathrm{a}, \mathrm{b}, \mathrm{c}, \mathrm{d})$ in the same column differ significantly at $p \leq 0.05$ using one way ANOVA test, while those with similar letters are non-significant.

Concerning body weight gain, the $\mathrm{C}$-ve group was $35.78 \pm 0.97 \%$ but in $\mathrm{C}+\mathrm{ve}$ group there was significant reduction at $10.24 \pm 0.62 \%$. A significant increase in $\mathrm{BWG} \%$ in $\mathrm{CCl}_{4}$-intoxicated rats and fed on all levels of M. chamomilla was observed compared to $\mathrm{C}+\mathrm{ve}$ group. There were non-significant changes between rats fed on $5 \%$ and $10 \%$ M. chamomilla which were $34.04 \pm 0.57$ and $33.58 \pm 0.45 \%$, respectively. There were also significant changes between rats fed on levels $20 \%$ and $25 \%$ for BWG\% which were $14.37 \pm 0.41$ and $13.73 \pm 0.53 \%$, respectively.

Regarding FER, it was found that in rats injected with $\mathrm{CCl}_{4}$ without treatment $(\mathrm{C}+\mathrm{ve}$ group), FER was $0.06 \pm 0.003$ while in normal rats $(\mathrm{C}$-ve $)$ it was $0.13 \pm 0.007$. These results denote that there was a significant decrease in FER of rats poisoned by $\mathrm{CCl}_{4}$ as compared to normal rats. Rats intoxicated by $\mathrm{CCl}_{4}$ and fed on formulas $5 \%$ and $10 \%$ did not show a significant increase in FER at $0.11 \pm 0.004$ and $0.11 \pm 0.006$, respectively. Similarly FER of groups fed with $15 \%$ and $20 \%$ of M. chamomilla showed values of $0.09 \pm 0.006$ and $0.08 \pm 0.004$ respectively, and the differences were non-significant. Meanwhile, rats treated with $\mathrm{CCl}_{4}$ and fed on $25 \% \mathrm{M}$. chamomilla showed significant increase in FER compared to $\mathrm{C}+\mathrm{ve}$ rats which were $0.07 \pm 0.004$ and $0.06 \pm 0.003$, respectively.

Dickerson and Lee (1988) reported that many patients with acute or chronic liver disease are ill, and commonly lose weight. Moreover, Clevely and Richmond (1998) concluded that $M$. chamomilla is medicinally valuable and for treatment of liver disorders.

\section{Effects on relative organs weight}

Data listed in Table III shows the effect of feeding at different plant concentration on relative organs weight of $\mathrm{CCl}_{4}$-intoxicated rats. There was a significant decrease in relative liver, spleen, lungs, heart and kidneys weight of rats poisoned by $\mathrm{CCl}_{4}$ as compared to the control (-ve) normal rats. For the relative weight of liver, there were non-significant differences between rats treated with $\mathrm{CCl}_{4}$ and those fed on $10 \%$ and $20 \%$ concentration of $M$. chamomilla. $\mathrm{CCl}_{4}$ treated rats fed on $5 \%$ concentration of $M$. chamomilla showed the most significant increase in the relative organ weight as compared to all levels of treatment, while $\mathrm{CCl}_{4}$ treated rats fed on $25 \%$ concentration of $M$. chamomilla showed the lowest significant increase as compared to all levels.

Regarding relative spleen weight, there were nonsignificant changes between rats injected with $\mathrm{CCl}_{4}$ and fed on $10 \%$ and $15 \%$ concentration of $M$. chamomilla. Meanwhile, there were non-significant changes between rats injected with $\mathrm{CCl}_{4}$ and fed on $20 \%$ and $25 \%$

Table III.- Effects of feeding with different levels of $M$. chamomilla on relative organ weight of $\mathrm{CCl}_{4}$-intoxicated rats (n=6rats).

\begin{tabular}{lccccc}
\hline Parameters / & \multicolumn{5}{c}{ Relative organs weight (g/100 g. B.Wt.) } \\
\cline { 2 - 5 } Groups & Liver & Spleen & Lungs & Heart & Kidneys \\
\hline Control - ve & $3.79 \pm 0.08^{\mathrm{b}}$ & $0.62 \pm 0.05^{\mathrm{a}}$ & $0.87 \pm 0.04^{\mathrm{a}}$ & $0.91 \pm 0.04^{\mathrm{a}}$ & $0.94 \pm 0.12^{\mathrm{a}}$ \\
Control + ve & $3.49 \pm 0.07^{\mathrm{e}}$ & $0.49 \pm 0.05^{\mathrm{d}}$ & $0.67 \pm 0.00^{\mathrm{d}}$ & $0.49 \pm 0.02^{\mathrm{d}}$ & $0.79 \pm 0.07^{\mathrm{d}}$ \\
$5 \%$ M. chamomilla & $4.09 \pm 0.09^{\mathrm{a}}$ & $0.62 \pm 0.01^{\mathrm{a}}$ & $0.83 \pm 0.01^{\mathrm{a}}$ & $0.87 \pm 0.01^{\mathrm{a}}$ & $0.93 \pm 0.06^{\mathrm{a}}$ \\
$10 \%$ M. chamomilla & $3.64 \pm 0.04^{\mathrm{c}}$ & $0.58 \pm 0.01^{\mathrm{b}}$ & $0.75 \pm 0.06^{\mathrm{b}}$ & $0.83 \pm 0.01^{\mathrm{a}}$ & $0.84 \pm 0.08^{\mathrm{b}}$ \\
$15 \%$ M. chamomilla & $3.72 \pm 0.05^{\mathrm{b}}$ & $0.56 \pm 0.03^{\mathrm{b}}$ & $0.74 \pm 0.02^{\mathrm{b}}$ & $0.61 \pm 0.01^{\mathrm{c}}$ & $0.83 \pm 0.02^{\mathrm{b}}$ \\
$20 \%$ M. chamomilla & $3.62 \pm 0.04^{\mathrm{c}}$ & $0.52 \pm 0.01^{\mathrm{c}}$ & $0.72 \pm 0.008^{\mathrm{b}}$ & $0.57 \pm 0.02^{\mathrm{c}}$ & $0.73 \pm 0.007^{\mathrm{c}}$ \\
$25 \%$ M. chamomilla & $3.59 \pm 0.02^{\mathrm{d}}$ & $0.51 \pm 0.01^{\mathrm{c}}$ & $0.69 \pm 0.01^{\mathrm{c}}$ & $0.77 \pm 0.01^{\mathrm{b}}$ & $0.71 \pm 0.009^{\mathrm{c}}$ \\
\hline
\end{tabular}

Values denote arithmetic means \pm Standard error of the mean. Means with different letters $(\mathrm{a}, \mathrm{b}, \mathrm{c}, \mathrm{d})$ in the same column differ significantly at $\mathrm{p} \leq 0.05 \mathrm{using}$ one way ANOVA test, while those with similar letters are non-significant. 
concentration of $M$. chamomilla, which were $0.52 \pm 0.019$ and $0.51 \pm 0.011 \mathrm{~g} / 100 \mathrm{~g} \mathrm{B.Wt}$., respectively. Rats poisoned by $\mathrm{CCl}_{4}$ and fed $5 \%$ concentration of $M$. chamomilla showed the highest significant increase in the mentioned relative organ weight which was $0.62 \pm 0.018 \mathrm{~g} / 100 \mathrm{~g}$ B.Wt., showing non-significant changes as compared to control $(-\mathrm{ve})$ normal rats.

Concerning relative lungs weight, there were nonsignificant changes between rats injected with $\mathrm{CCl}_{4}$ then fed on levels $10 \%, 15 \%$ and $20 \%$ of $M$. chamomilla. Rats fed on 5\% M. chamomilla showed the highest significant increase in lung weight which was $0.83 \pm 0.014 \mathrm{~g} / 100 \mathrm{~g}$ B.Wt. Meanwhile, it did not reflect any significant change as compared to control (-ve) normal rats which was $0.87 \pm 0.41 \mathrm{~g} / 100 \mathrm{~g} \mathrm{~B}$.Wt.

Relative heart weight showed no significant changes between rats treated with $\mathrm{CCl}_{4}$ and then fed on $5 \%$, and $10 \%$ concentration levels of $M$. chamomilla. At the same time, there were also non-significant differences between rats given $\mathrm{CCl}_{4}$ then fed on levels $15 \%$ and $20 \%$. The highest significant value in mentioned organs were noticed in $\mathrm{CCl}_{4}$ treated rats fed on $5 \%$ and $10 \% \mathrm{M}$. chamomillaas compared to control (+ve) group.

Kidneys relative weight showed non-significant differences between rats given $\mathrm{CCl}_{4}$ then fed on $10 \%$ and $15 \%$ concentration of $M$. chamomilla. Also, there were non-significant changes between rats injured by $\mathrm{CCl}_{4}$ then fed on $20 \%$ and $25 \%$ of $M$. chamomilla. $\mathrm{CCl}_{4}$ treated rat $\mathrm{s}$ fed on $5 \%$ concentration of $M$. chamomilla showed the highest significant increase among the mentioned relative weights which was $0.93 \pm 0.064 \mathrm{~g} / 100 \mathrm{~g} \mathrm{~B}$.Wt., and showed non-significant change as compared to that of $(\mathrm{C}-\mathrm{ve})$ normal rats. From the present findings, it can be concluded that carbon tetrachloride $\mathrm{CCl}_{4}$ decreased liver weight and induced the atrophy, however, a diet consisting of $5 \%$ and $10 \%$ concentration of $M$. chamomilla can reduced severity of this, and showing an increased organ weight, indicating reduced atrophy from liver damage caused by $\mathrm{CCl}_{4}$. The decrease in liver weight following $\mathrm{CCl}_{4}$ treatment may be attributed to progressive liver damage due to $\mathrm{CCl}_{4}$ induced toxicity (Aksoy and Sozbilir, 2012).

\section{Biochemical analysis}

Tables IV, V and VI shows the effect of different concentration levels of $M$. chamomilla on liver enzymes, total protein and total bilirubin, total cholesterol and triglycerides, and lipoprotein fractions in $\mathrm{CCl}_{4}$-intoxicated rats. Table IV shows the effect of different levels of $M$. chamomilla on serum liver enzymes including aspartate amino transaminase (AST), alanine amino transferase (ALT) and alkaline phosphatase (ALP) enzymes in $\mathrm{CCl}_{4}^{-}$ intoxicated rats. It is reported in the literature that these enzyme markers are used in diagnosis of liver disorders, the concentration of which increases during liver injury or cell damage (Chani and Jasim, 2016). Their increase in the serum has been attributed to the leakage of these enzymes from damaged hepatocytes (Yang et al., 2008).

Table IV.- Effects of different levels of $M$. chamomilla $(5 \%, 10 \%, 15 \%, 20 \%, 25 \%)$ on serum levels of aspartate amino transaminase (AST), alanine amino transferase (ALT) and alkaline phosphatase (ALP) enzymes of $\mathrm{CCl}_{4}$-intoxicated rats $(\mathrm{n}=6$ rats $)$.

\begin{tabular}{lccc}
\hline $\begin{array}{l}\text { Parameters } / \\
\text { Groups }\end{array}$ & AST (U/L)* & ALT (U/L)* & ALP (U/L)* \\
\hline Control - ve & $65.6 \pm 1.8^{\mathrm{e}}$ & $36.5 \pm 1.6^{\mathrm{e}}$ & $84.5 \pm 1.9^{\mathrm{e}}$ \\
Control + ve & $130.6 \pm 2.1^{\mathrm{a}}$ & $70.5 \pm 2.4^{\mathrm{a}}$ & $159.4 \pm 2.7^{\mathrm{a}}$ \\
$5 \%$ M. chamomilla & $124.6 \pm 2.3^{\mathrm{b}}$ & $65.5 \pm 2.8^{\mathrm{b}}$ & $154.7 \pm 2.5^{\mathrm{b}}$ \\
$10 \%$ M. chamomilla & $118.3 \pm 2.4^{\mathrm{c}}$ & $46.7 \pm 2.2^{\mathrm{c}}$ & $146.3 \pm 2.8^{\mathrm{c}}$ \\
$15 \%$ M. chamomilla & $114.8 \pm 2.1^{\mathrm{c}}$ & $40.5 \pm 2.6^{\mathrm{c}}$ & $139.5 \pm 2.2^{\mathrm{c}}$ \\
20\% M. chamomilla & $113.5 \pm 1.6^{\mathrm{c}}$ & $35.5 \pm 1.9^{\mathrm{c}}$ & $135.5 \pm 1.2^{\mathrm{c}}$ \\
$25 \%$ M. chamomilla & $94.7 \pm 2.4^{\mathrm{d}}$ & $30.3 \pm 2.7^{\mathrm{d}}$ & $114.2 \pm 2.9^{\mathrm{d}}$ \\
\hline
\end{tabular}

$(\mathrm{U} / \mathrm{L})^{*}$, unit per liter. Values denote arithmetic means \pm standard error of the mean. Means with different letters (a, b, c, d) in the same column differ significantly at $\mathrm{p} \leq 0.05$ using one way ANOVA test, while those with similar letters are non-significant.

It is clear from the Table IV that in rats intoxicated with $\mathrm{CCl}_{4}$ without treatment, the serum levels of AST, ALT and ALP enzymes were 130.6 $\pm 2.1,70.5 \pm .4$ and $159.4 \pm 2.7$ $\mathrm{U} / \mathrm{L}$, respectively. In (C -ve) normal rats, the serum levels of the mentioned enzymes were $65.6 \pm 1.8,36.5 \pm 1.6$ and $84.5 \pm 1.9 \mathrm{U} / \mathrm{L}$, respectively. In this study there was a significant increase of AST, ALT and ALP enzymes in the serum of rats poisoned by $\mathrm{CCl}_{4}$ as compared to $(\mathrm{C}-\mathrm{ve})$ normal rats (Aksoy and Sozbilir, 2012). Rats given $\mathrm{CCl}_{4}$ then fed on different concentration $(5 \%, 10 \%, 15 \%$, and $20 \%$ ) of $M$. chamomilla had a significant decrease in serum levels of AST, ALT and ALP activities. Rats given $\mathrm{CCl}_{4}$ then fed on a combination of all levels of treatment showed a decrease of AST, ALT and ALP enzyme levels in the serum. The decrease in serum AST, ALT and ALP enzyme levels reached to $94.7 \pm 2.4,30.3 \pm 2.7$ and 114.2 $\pm 2.9 \mathrm{U} / \mathrm{L}$, respectively. The results corroborate with some of the earlier findings (Troudi et al., 2012; Sancheti et al., 2013; Chain and Jasim, 2016).

In this study, treatment with $\mathrm{CCl}_{4}$ showed a positive result for liver damage while treatment with $M$. chamomilla at different concentrations rescued this phenotype. An increase in these liver enzymes indicate a pathological phenotype. However, treatment with M. chamomilla 
Table V.- Effects of different concentration levels $(5 \%, 10 \%, 15 \%, 20 \%, 25 \%)$ of $M$. chamomilla on serum levels of total protein, total bilirubin, total cholesterol and triglycerides of $\mathrm{CCl} 4$-intoxicated rats ( $\mathrm{n}=6$ rats).

\begin{tabular}{lcccc}
\hline $\begin{array}{l}\text { Parameters / } \\
\text { Groups }\end{array}$ & $\begin{array}{c}\text { Total protein } \\
(\mathbf{m g} / \mathbf{d l})\end{array}$ & $\begin{array}{c}\text { Total bilirubin } \\
(\mathbf{m g} / \mathbf{d l})\end{array}$ & $\begin{array}{c}\text { Total cholesterol } \\
(\mathbf{m g} / \mathbf{d l})\end{array}$ & $\begin{array}{c}\text { Triglycerides } \\
(\mathbf{m g} / \mathbf{d l})\end{array}$ \\
\hline Control - ve & $6.68 \pm 1.3^{\mathrm{a}}$ & $0.66 \pm 0.01^{\mathrm{b}}$ & $88.98 \pm 1.4^{\mathrm{d}}$ & $43.35 \pm 1.5^{\mathrm{d}}$ \\
Control + ve & $4.65 \pm 1.6^{\mathrm{b}}$ & $0.99 \pm 0.01^{\mathrm{a}}$ & $105.95 \pm 1.6^{\mathrm{a}}$ & $56.60 \pm 1.9^{\mathrm{a}}$ \\
$5 \%$ M. chamomilla & $6.54 \pm 1.8^{\mathrm{a}}$ & $0.83 \pm 0.01^{\mathrm{b}}$ & $101.97 \pm 1.8^{\mathrm{b}}$ & $52.60 \pm 1.4^{\mathrm{b}}$ \\
$10 \%$ M. chamomilla & $6.55 \pm 1.2^{\mathrm{a}}$ & $0.80 \pm 0.01^{\mathrm{b}}$ & $98.90 \pm 1.2^{\mathrm{c}}$ & $49.50 \pm 1.2^{\mathrm{c}}$ \\
$15 \%$ M. chamomilla & $6.53 \pm 1.3^{\mathrm{a}}$ & $0.75 \pm 0.01^{\mathrm{b}}$ & $102.26 \pm 1.3^{\mathrm{b}}$ & $54.30 \pm 1.4^{\mathrm{b}}$ \\
$20 \%$ M. chamomilla & $6.54 \pm 1.5^{\mathrm{a}}$ & $0.70 \pm 0.01^{\mathrm{b}}$ & $95.90 \pm 1.5^{\mathrm{c}}$ & $46.50 \pm 1.3^{\mathrm{c}}$ \\
$25 \%$ M. chamomilla & $6.53 \pm 1.1^{\mathrm{a}}$ & $0.69 \pm 0.01^{\mathrm{b}}$ & $90.45 \pm 1.1^{\mathrm{d}}$ & $40.50 \pm 1.4^{\mathrm{d}}$ \\
\hline
\end{tabular}

Values denote arithmetic means \pm Standard error of the mean. Means with different letters $(\mathrm{a}, \mathrm{b}, \mathrm{c}, \mathrm{d})$ in the same column different significantly at $p \leq 0.05$ using one way ANOVA test, while those with similar letters are non-significant.

at increasing concentrations reduced the levels of these enzymes which are a positive result for treating liver damage and should be considered for patients suffering from this disease. The present results corroborate with the findings of Aksoy and Sozbilir (2012). Whereby, ALT and AST enzymes were significantly increased in the $\mathrm{CCl}_{4}$ group indicating liver damage, but simultaneous treatment with M. chamomilla reduced oxidative stress and antioxidant activity.

\section{Effects on total protein and total bilirubin}

Table V shows the effects of different concentration levels of M. chamomilla on serum levels of total protein, total bilirubin, total cholesterol and triglycerides of $\mathrm{CCl}_{4}$ intoxicated rats. Serum levels of total protein and total bilirubin in $\mathrm{C}+\mathrm{ve}$ group were $4.65 \pm 1.6$ and $0.99 \pm 0.012$ $\mathrm{mg} / \mathrm{dl}$, respectively. While in the $\mathrm{C}-\mathrm{ve}$ normal rats were $6.68 \pm 1.3$ and $0.66 \pm 0.011 \mathrm{mg} / \mathrm{dl}$, respectively. These results revealed a significant decrease in total protein but significant increase in total bilirubin in the serum of rats intoxicated by $\mathrm{CCl}_{4}$ as compared to $\mathrm{C}$-ve normal rats. The result is in consistent with earlier findings, demonstrating increased serum total bilirubin and decreased serum total protein in $\mathrm{CCl}_{4}$-induced hepatotxicity in rats (Sancheti et al., 2013). In $\mathrm{CCl}_{4}$ treated rats fed on all levels of $M$. chamomilla, there was a significant increase in the serum level of total protein, but a significant decrease in serum level of total bilirubin. However, between groups there was a not significant change, which suggests that concentrations of $M$. chamomilla does not affect the total protein and bilirubin levels and is not effective for this purpose. As increased bilirubin levels are an indicator of liver damage it may be necessary to use higher concentrations of $M$. chamomilla to achieve a significant decrease in bilirubin levels, so as to aid in the treatment of liver damage. Thus, enhancements in serum ALT, AST and total bilirubin is an indicative of $\mathrm{CCl}_{4}$-induced hepatic injury in rats (Drotman and Lawhorn, 1978). M. chamomilla caused significant decreased the levels of serum ALT, AST and total bilirubin, suggesting its protective function against $\mathrm{CCl}_{4}$-induced liver damage.

In rats injected with $\mathrm{CCl}_{4}$ and without treatment $(\mathrm{C}$ $+v e$ ), levels of total cholesterol and triglycerides were $105.95 \pm 1.6$ and $56.60 \pm 1.9 \mathrm{mg} / \mathrm{dl}$, compared to $88.98 \pm 1.4$ and $53.35 \pm 1.5 \mathrm{mg} / \mathrm{dl}$ in normal rats $(\mathrm{C}-\mathrm{ve})$. The obtained results showed that there was a significant increase in serum levels of total cholesterol and triglycerides in rats poisoned by $\mathrm{CCl}_{4}$ as compared to normal rats. In $\mathrm{CCl}_{4}$ treated rats fed on all levels of treatment, there was a significant decrease in serum levels of total cholesterol and triglycerides as compared to $\mathrm{C}+\mathrm{ve}$ group. The result corroborate with earlier findings (Nargesi et al., 2018). The lowest levels of cholesterol and triglycerides were observed in the group treated with $25 \%$ of M. chamomilla.

There were non-significant differences between 5\% and $15 \%$ M. chamomilla which were $101.97 \pm 1.8$ and $102.26 \pm 1.3 \mathrm{mg} / \mathrm{dl}$ for total cholesterol and were $52.60 \pm 1.4$ and $54.30 \pm 1.4 \mathrm{mg} / \mathrm{dl}$, respectively for triglycerides. Also, there were non-significant differences between $10 \%$ and $20 \%$ M. chamomilla which showed $98.90 \pm 1.2$ and $95.90 \pm 1.5 \mathrm{mg} / \mathrm{dl}$ for total cholesterol and $49.50 \pm 1.2$ and $46.50 \pm 1.3 \mathrm{mg} / \mathrm{dl}$, respectively for triglycerides. Meanwhile, $25 \%$ M. chamomilla showed the highest significant decrease both in total cholesterol and triglycerides as compared to all levels of treatment, and revealed non-significant differences compared with $(\mathrm{C}-$ ve) normal rats as regards both parameters. Similar results were observed by Tsi and Tan (1996).

Table VI shows the effects of different concentration levels of $M$. chamomilla on the serum levels of lipoprotein fraction (HDLc, LDLc and VLDLc) in $\mathrm{CCl}_{4}$-intoxicated rats. There was a significant increase in HDLc, LDLc 
and VLDLc lipoprotein fractions in the serum of rats poisoned by $\mathrm{CCl}_{4}$ and without treatment as compared to the control $(-\mathrm{ve})$ normal rats. In $\mathrm{C}+\mathrm{ve}$ rat serum levels of HDLc, LDLc and VLDLc were $75.69 \pm 1.2,18.64 \pm 1.4$ and $11.32 \pm 1.6 \mathrm{mg} / \mathrm{dl}$, respectively. In normal rats $(\mathrm{C}-\mathrm{ve})$ the serum levels of lipoprotein fractions were $63.96 \pm 1.1$, $16.35 \pm 1.2$ and $8.67 \pm 1.1 \mathrm{mg} / \mathrm{dl}$, respectively. Rats injected with $\mathrm{CCl}_{4}$ and fed on $10 \%$ and $20 \%$ M. chamomilla had a significant decrease in high density lipoprotein (HDL-c) while those fed on all levels had a significant decrease in low and very low density lipoprotein (LDLc and VLDLc) as compared to control +ve group. The result is consistent with previous studies (Nargesi et al., 2018). With regard to Lipoprotein fraction HDL, there was no significant differences between $\mathrm{C}+$ ve rats treated with $\mathrm{CCl}_{4}$ and fed on $5 \%$ and $15 \%$ concentration of $M$. chamomilla compared to control (+ve) group which were $74.75 \pm 1.3,73.70 \pm 1.7$ and $75.69 \pm 1.2 \mathrm{mg} / \mathrm{dl}$, respectively. Also, rats injured by $\mathrm{CCl}_{4}$ and fed on $5 \%, 10 \%$ and $20 \% \mathrm{M}$. chamomilla showed lipoprotein fraction LDLc of $16.70 \pm 1.3,16.90 \pm 1.3$ and $16.50 \pm 1.4 \mathrm{mg} / \mathrm{dl}$, respectively. Regarding lipoprotein fraction VLDc, there were non-significant differences between rats given $\mathrm{CCl}_{4}$ then fed on $5 \%$ and $15 \% M$. chamomilla, which were $10.52 \pm 1.8$ and $10.86 \pm 1.8 \mathrm{mg} / \mathrm{dl}$, respectively. Also, there were non-significant differences between rats given $\mathrm{CCl}_{4}$ and fed on $10 \%$ and $20 \% \mathrm{M}$. chamomilla, which were $9.90 \pm .1$ and $9.30 \pm 1.1 \mathrm{mg} / \mathrm{dl}$, respectively. Finally, rats treated with $\mathrm{CCl}_{4}$ prior to feeding on all levels of treatments revealed the highest decrease in serum lipoprotein HDL, LDL, VLDL fraction levels which reached to $68.85 \pm 1.6,13.50 \pm 1.3$ and $8.10 \pm 1.2$ $\mathrm{mg} / \mathrm{dl}$, respectively. Similar results were obtained by

Table VI.- Effects of different concentration levels $(5 \%, 10 \%, 15 \%, 20 \%, 25 \%)$ of $M$. chamomilla on the serum levels of lipoprotein fractions (HDLc, LDLc and VLDLc) in $\mathrm{CCl}_{4}$-intoxicated rats ( $\mathrm{n}=6$ rats).

\begin{tabular}{lccc}
\hline Parameters / & \multicolumn{3}{c}{ Lipoprotein fractions (mg/dl) } \\
\cline { 2 - 4 } Groups & HDLc & LDLc & VLDLc \\
\hline Control - ve & $63.96 \pm 1.1^{\mathrm{e}}$ & $16.35 \pm 1.2^{\mathrm{c}}$ & $8.67 \pm 1.1^{\mathrm{d}}$ \\
Control + ve & $75.99 \pm 1.2^{\mathrm{a}}$ & $18.64 \pm 1.4^{\mathrm{a}}$ & $11.32 \pm 1.6^{\mathrm{a}}$ \\
$5 \%$ M. chamomilla & $74.75 \pm 1.3^{\mathrm{b}}$ & $16.70 \pm 1.3^{\mathrm{c}}$ & $10.52 \pm 1.8^{\mathrm{b}}$ \\
$10 \%$ M. chamomilla & $72.10 \pm 1.3^{\mathrm{c}}$ & $16.90 \pm 1.3^{\mathrm{c}}$ & $9.90 \pm 1.1^{\mathrm{c}}$ \\
$15 \%$ M. chamomilla & $73.70 \pm 1.7^{\mathrm{b}}$ & $17.70 \pm 1.3^{\mathrm{b}}$ & $10.86 \pm 1.8^{\mathrm{b}}$ \\
$20 \%$ M. chamomilla & $70.10 \pm 1.2^{\mathrm{c}}$ & $16.50 \pm 1.4^{\mathrm{c}}$ & $9.30 \pm 1.1^{\mathrm{c}}$ \\
$25 \%$ M. chamomilla & $68.85 \pm 1.6^{\mathrm{d}}$ & $13.50 \pm 1.3^{\mathrm{d}}$ & $8.10 \pm 1.2^{\mathrm{d}}$ \\
\hline
\end{tabular}

Values denote arithmetic means \pm Standard error of the mean. Means with different letters $(\mathrm{a}, \mathrm{b}, \mathrm{c}, \mathrm{d})$ in the same column different significantly at $p \leq 0.05$ using one way ANOVA test, while those with similar letters are non-significant.
Williams et al, 2014. It has been reported elsewhere that M. chamomilla reduces intestinal absorption of lipids (Tavakol et al., 2014).

Thus M.chamomilla seem tobepotenthepatoprotective agent in maintaining healthy liver, elucidating its possible therapeutic applications. However, further in-depth studies on histological aspects are warranted to confirm their pharmacotherapeutic significance.

\section{CONCLUSION}

This study showed that different concentration levels of $M$. chamomilla in the diet of rats suffering from liver damage aided in their recovery and decreased pathological levels of enzymes and cholesterol in the body. However, the use of $M$. chamomilla to decrease bilirubin levels was not significant, indicating that a higher concentration of M. chamomilla in the diet may be required in some cases. The only limitation in the present study is the histological examination of liver sections of $M$. chamomilla administered mice. Further studies on histological properties may expose positive results on degenerative changes of liver tissues. Overall findings indicate that appropriate tuning of doses of $M$. chamomilla is required for different treatment purposes. This study proves that plant materials possess the ability to aid in improving liver function primarily by reducing serum liver enzymes. The use of M. chamomilla would be beneficial for patients with liver disorders but $5-10 \%$ concentration would be the most effective in this case.

Statement of conflict of interest

The authors declare no conflict of interest.

\section{REFERENCES}

Aksoy, L. and Sozbilir, N.B., 2012. Effects of Matricaria chamomilla L. on lipid peroxidation, antioxidant enzyme systems, and key liver enzymes in CCl4treated rats. Toxicol. environ. Chem., 94: 17801788. https://doi.org/10.1080/02772248.2012.729 837

Bhattacharjee, R. and Sil, P.C., 2007. Protein isolate from the herb, Phyllanthus niruri L. (Euphorbiaceae), plays hepatoprotective role against carbon tetrachloride induced liver damage via its antioxidant properties. Fd. Chem. Toxicol., 45: 817-826. https://doi.org/10.1016/j.fct.2006.10.029

Chapman, D.G., Castilla, R. and Campbell, J.A., 1959. Evaluation of protein in food. I: A method for the determination of protein efficiency ratio. Can. J. Biochem. Phosiol., 37: 679-686. https://doi. 
org/10.1139/y59-074

Campbell, J.A., 1963. Methodology of protein evaluation. RAG Nutr., Document R.10, Led. 37. New York.

Chani, J.M. and Jasim, N.Z., 2016. Hepatoprotective effect of Matricaria chamomilla hot aqueous extract against methomyl 90\%-induced hepatotoxicity in mice. Al-Kufa Univ. J. Biol., 8: 185-195.

Clevely, A. and Richmond, K., 1998. The new guide to herbs. Lorenz Books, Anness Publishing Limited.

Dickerson, J.W. and Lee, H.A., 1988. Nutrition in the clinical management of disease, Second edition. Edward Arnold.

Doumas, B.T., Ferry, B.W., Sasse, E.A. and Straum, J.V., 1973. Cited in the pamphlet of Quimica. Clin. Apli. Amp. Spain. Clin. Chem., 19; 984-993.

Drotman, R.B. and Lawhorn, G.T., 1978. Serum enzymes as indicators of chemical induced liver damage. Drug Chem. Toxicol., 1: 163-171. https:// doi.org/10.3109/01480547809034433

Drury, R.A. and Wallington, E.A., 1967. Carton's histological technique, $5^{\text {th }}$ ed. Oxford University Press.

Fnedewaid, W.T., 1972. Determination of HDL. Clin. Chem., 18: 499.

Gordon, T. and Amer, M., 1977. Determination of HDL. J. Med., 62: 707.

Guan, Y.S. and He, Q., 2015. Plants consumption and liver health. Evidence-Based Complem. Altern. Med., 2015: Article ID 824185. https://doi. org/10.1155/2015/824185

Hegsted, D., Mills, R. and Perkins, E., 1941. Salt mixture. J. biol. Chem., 138: 459.

Jacobs, N.J. and van Denmark, P.J., 1960. Determination of triglycerides. Arch. Biochem. Biophys., 88: 250255. https://doi.org/10.1016/0003-9861(60)902307

Jayasekhar, P., Mohanan, P.V. and Rahinam, K., 1997. Hepatoprotective activity of ethyl acetate extract of Acacia catechu. Indian J. Pharmacol., 29: 426-428.

Kuntz, E. and Kuntz, H.D., 2005. Hepatology: History, morphology, biochemistry, diagnostics, clinic, therapy. Birkhäuser, Heidelberg, Germany, pp. $52-53$.

Lee, R.D. and Nieman, D.C., 1996. Nutritional assessment, $2^{\text {nd }}$ ed. Mosby, Missoun, USA.

Passmore, R. and Eastwood, M.A., 1986. Human nutrition and dietetics, Eight edition. Longman Group Ltd., Churchill Livingstone, UK.

Madrigal-Santillán, E., Madrigal-Bujaidar, E., ÁlvarezGonzález, I., Sumaya-Martinez, M.T., GutierrezSalinas, J., Bautista, M., Morales-Gonzalez, A.,
Garcia-Luna, M., Gonzalez-Rubio, Y., AguilarFaisal, J.L. and Morales-Gonzalez, J.A., 2014. Review of natural products with hepatoprotective effects. World J. Gastroenterol., 20: 14787-14804.

Nargesi, S., Moayeri, A., Ghorbani, A., Seifinejad, Y., Shirzadpour, E. and Amraei, M., 2018. The effects of Matricaria chamomilla L. hydroalcoholic extract on atherosclerotic plaques, antioxidant activity, lipid profile and inflammatory indicators in rats. Biomed. Res. Ther., 5: 2752-2761. https:// doi.org/10.15419/bmrat.v5i10.490

Ratliff, C.R. and Hall, F., 1973. A new method for direct colorimetric determination of serum cholesterol. In: Laboratory manual of clinical biochemistry. Scoot and White Memorial Hospital Publications, Temple, TX, USA.

Reeves, P.G., Nielson, F.H. and Fahmy, G.C.,1993. Reports of the American Institute of Nutrition, adhoc wiling committee on reformulation of the AIN 93. Rodent Diet. J. Nutri., 123: 1939-1951. https://doi.org/10.1093/jn/123.11.1939

Reitman, S. and Frankel, S., 1957. Colorimetric method for aspartate and alanine aminotransferase. Am. J. clin. Path., 28: 26. https://doi.org/10.1093/ ajcp/28.1.56

Roy, S.E., 1970. Colorimetric determination of serum alkaline phosphatase. Clin. Chem., 16: 431-432.

Sancheti, S., Sancheti, S. and Seo, S.Y., 2013. Ameliorative effects of 7-methylcoumarin and 7-methoxycoumarin against CCl4-induced hepatoxicity in rats. Drug Chem. Toxicol., 36: 4247. https://doi.org/10.3109/01480545.2011.648329

Snedecor, G.W. and Cochran, W.G., 1967. Statistical methods, $6^{\text {th }}$ ed. Iowa State University Press, Ames, Iowa, USA.

Singh, O., Khanam, Z., Misra, N. and Srivastava, M.K., 2011. Chamomile (Matricaria chamomilla L.): An overview. Pharmacog. Rev., 5: 82-95. https://doi. org/10.4103/0973-7847.79103

Srivastava, J.K., Shankar, E. and Gupta, S., 2010. Chamomile: A herbal medicine of the past with bright future. Mol. Med. Rep., 3: 895-901. https:// doi.org/10.3892/mmr.2010.377

Tavakol, H.S., Farzad, K., Fariba, M., Abdolkarim, C., Hassan, G., Seyed-Mostafa, H.Z. and Akram, R., 2014. Hepatoprotective effect of Matricaria chamomilla L. in paraquat induced rat liver injury. Drug Res., 64: 1-5. https://doi. org/10.1055/s-0033-1363999

Troudi, A., Amara, I., Samet, A. and Zeghal, N., 2012 Oxidative stress induced by 2, 4-phenoxyacetic acid in liver of female rats and their progeny: 
Biochemical and histopathological studies. Environ. Toxicol., 27: 137-145. https://doi.org/10.1002/ tox. 20624

Tsi, D. and Tan, B.K., 1996. Effects of celery extract and 3-N-butylphthalide on lipid levels in genetically hypercholesterolaemic (RICO) rats. Clin. exp. Pharmacol. Physiol., 23: 214-217. https://doi. org/10.1111/j.1440-1681.1996.tb02598.x

Williams, J.A., Manley, S. and Ding, W.X., 2014. New advances in molecular mechanisms and emerging therapeutic targets in alcoholic liver diseases. World J. Gastroenterol., 20: 12908-12933. https:// doi.org/10.3748/wjg.v20.i36.12908

Yang, Y.S., Ahn, T.H, Lee, J.C., Moon, C.J., Kim, S.H., Jun, W., Park, S.C., Kim, H.C. and Kim, J.C., 2008. Protective effects of Pycnogenol on carbon tetrachloride-induced hepatotoxicity in Sprague Dawley rats. Fd. Chem. Toxicol., 46: 380-387. https://doi.org/10.1016/j.fct.2007.08.016 